\title{
Effects of food waste compost on the shift of microbial community in water saturated and unsaturated soil condition
}

\author{
Chang Hoon Lee', Seong Jin Park², Hyun Young Hwang ${ }^{2}$, Myung Sook Kim², Ha il Jung ${ }^{2}$, Deogratius Luyima ${ }^{3}$, \\ Suk Young Hong ${ }^{2}$, Taek Keun $\mathrm{Oh}^{3^{*}}$ and Seong Heon $\mathrm{Kim}^{2^{*}}$ (1)
}

\begin{abstract}
Despite the widespread use of food waste compost as a soil organic amendment, there is limited information on how it affects the composition of the microbial community as well as its relationship on soil environmental factors. This study investigated the effects of food waste compost on soil microbial-community composition by using FAME analysis. It was established that the application of food waste composts in water saturated paddy and unsaturated upland soils increased pH levels, electrical conductivity (EC) values, total carbon (TC), and ESP contents. It also increased the total phospholipid fatty acid (T-PLFA) and fungi resulting in a significant rise in the fungi to bacterial ratio. Furthermore, microbial community composition shifted depending on the quantity of food waste compost applied after crop harvest in both paddy and upland soils. Also, a positive correlation was found between changes in soil microbial community and changes in TC, EC, and water availability for crop growth. These results suggest that soil fertility and its microbial composition depends on the amount of food waste compost applied in both water saturated the paddy and unsaturated upland soils.
\end{abstract}

Keywords: Food waste compost, Microbial community, Water saturation, Carbon, Salinity

\section{Introduction}

More than 5 million tons of food waste is produced in Korea annually, of which approximately $40 \%$ is recycled through composting [1]. Food waste compost supplies organic matter that confers significant improvement of soil properties such as soil bulk density and water holding capacity, etc. [2]. With inherently higher N, P and K concentrations amounting to 4,2 and $1 \%$ respectively, food waste compost could be harnessed as a fertilizer for crop production [3]. The major impediment to its usage in agricultural production is the potential risk of inducing soil salinity since food waste is contaminated with salt.

\footnotetext{
*Correspondence: ok5382@cnu.ac.kr; ksh4054@korea.kr

${ }^{2}$ Soil and Fertilizer Division, National Institute of Agriculturaal Sciences,

RDA, Wanju 55365, Korea

${ }^{3}$ Department of Bio-Environmental Chemistry, Chungnam National

University, Daejeon 34134, Korea

Full list of author information is available at the end of the article
}

High salinity in food waste results in poor stabilization, lower efficiency of solids degradation during the composting process [4], and incomplete maturity of food waste compost. Consequently, $\mathrm{NaCl}$ content typifying salinity in food waste compost was established below $2 \%$ by law for sustainable crop cultivation. However, there is limited information on the effects of food waste compost on relation to soil productivity and properties. Application of food waste compost to soil culminates into increased $\mathrm{pH}$ and in electrical conductivity (EC) due to the supply of $\mathrm{Na}$ ions to the soil [3]. However, sodium $(\mathrm{Na})$ input from food waste compost, might have a negative effect on the microbial process due to the induced-high osmotic pressure induced concomitantly scaling-down crop productivity.

Soil microorganisms are the engine of nutrient cycling. Soil microbes degrade soil organic materials in the soil releasing nutrients for plant uptake through the mineralization process with the rate of all these processes 
dependent on microbial population and activity. Generally, organic amendment in arable soil might stimulate microbial activity $[1,5]$, and a shift in microbial community composition [6]. These shifts are induced alongside changes in water contents, carbon substrate, and soil $\mathrm{pH}$ depending on the crop cultivation condition such as fertilization and irrigation [7], which also can in turn alter soil fertility and crop production $[8,9]$. We hypothesized that water management regimes in upland and lowland could be the main factor influencing microbial community composition, because microbial species was adapted to soil environmental conditions. Unfortunately, there is little information on the relationship between soil properties and microbial community composition in different water management regimes $[10,11]$. Therefore, this study aimed to evaluate the effect of food waste compost addition on soil chemical properties and microbial community composition using a biomarker of fatty acid in upland and lowland cultivation condition.

\section{Materials and methods Experimental setup}

The soil used for this study was Wansan series, a member of the fine loamy, micaceous, mesic family of Typic Hapludults, located in the National Institute of Agricultural Science (NAS) experiment area $\left(35^{\circ} 49^{\prime} 28.61^{\prime \prime} \mathrm{N}\right.$, $127^{\circ} 2^{\prime} 42.77^{\prime \prime} \mathrm{E}$ ). The soil $\mathrm{pH}$ and electrical conductivity (EC) were 7.28 and $0.73 \mathrm{dS} \mathrm{m}{ }^{-1}$, respectively, and soil organic carbon was $17.3 \mathrm{~g} \mathrm{~kg}^{-1}$ (Table 1). The soils were root-picked and sieved with a $4 \mathrm{~mm}$ mesh sieve before the pot experiment. The food waste compost contained $41.4 \%, 3.0 \%, 3.29 \%$, and $1.20 \%$ of total C, N, P and K, respectively (Table 2). The experiment was conducted with two treatment factors which included water management in both lowland (rice) and upland (pepper) conditions, and the levels of food waste compost applied to the soil. Food waste compost was applied to the soil at five different rates of $0,10,20,40$, and $60 \mathrm{Mg} \mathrm{ha}^{-1}$ of fresh materials (about $50 \%$ of water content) with each of the rates replicated thrice. Each Wagner pot $(25 \mathrm{~cm}$ in diameter and $30 \mathrm{~cm}$ in height) was filled with $14.7 \mathrm{~kg}$ of soil and adjusted to a bulk density of $1.2 \mathrm{~g} \mathrm{~cm}^{-3}$. Then, rice (Oryza sativa L.) and pepper (Capsicum annuum L.) were transplanted into Wagner pots on June 15, 2015 and were kept under greenhouse conditions. For rice and pepper cultivation, inorganic fertilizers were applied at nitrogen $(\mathrm{N})$-phosphorus (P)-potassium $(\mathrm{K})$ 110-45-57 and 190-112-149 $\mathrm{kg} \mathrm{ha}^{-1}$, respectively. The basal fertilizer application supplied $50 \%, 100 \%$, and $50 \%$ of $\mathrm{N}, \mathrm{P}$, and $\mathrm{K}$, respectively. $20 \%$ of $\mathrm{N}$ was top-dressed on the 15 th day after transplanting, and the remainder (30\%) of $\mathrm{N}$ and $\mathrm{K}$ were applied during near heading.

\section{Sampling and analysis}

Soil samples for soil properties and microbial community composition were collected at the surface soil $(0-10 \mathrm{~cm})$ of rhizosphere in each pot treatment by a core with $2 \mathrm{~cm}$ diameter after crop harvest. The soil sample was divided into two groups. One group was dried with air drying condition, and sieved $2 \mathrm{~mm}$ mesh for chemical properties. The other soil sample was stored at $-80^{\circ} \mathrm{C}$ and lyophilized for before FAME analysis. Soil $\mathrm{pH}$ and EC were determined through a suspension sample with a soil to water ratio of $1: 5$ and were measured using digital $\mathrm{pH}$ and EC meter. Soil organic carbon and total nitrogen were determined by the elemental analyzer (Vario Max, Elmentar). Soil available phosphate $\left(\mathrm{Av} . \mathrm{P}_{2} \mathrm{O}_{5}\right)$ was analyzed by Lancaster Methods (NAE, 2001). Briefly, $5 \mathrm{~g}$ of soil was extracted by mixture solution $(\mathrm{pH} 4.25)$ with $0.33 \mathrm{M}$ acetic acid, $0.15 \mathrm{M}$ lactic acid, $0.03 \mathrm{M}$ ammonium fluoride $0.05 \mathrm{M}$ ammonium sulfate, and $0.2 \mathrm{M}$ sodium hydroxide. Exchangeable sodium (Ex. Na) and cation exchange capacity (CEC) were determined using $1 \mathrm{M}$ ammonium acetate at $\mathrm{pH}$ 7.0. Firstly, $5 \mathrm{~g}$ of soil was

Table 1 Chemical properties of the basic soil used in the experiment

\begin{tabular}{|c|c|c|c|c|c|c|c|c|c|}
\hline \multirow[t]{3}{*}{ Soil texture } & \multirow[t]{3}{*}{$\mathrm{pH}(1: 5)$} & \multirow[t]{3}{*}{$\mathrm{EC}\left(\mathrm{dS} \mathrm{m^{-1 } )}\right.$} & \multirow[t]{3}{*}{$\mathrm{OM}\left(\mathrm{g} \mathrm{kg}^{-1}\right)$} & \multirow[t]{3}{*}{ Av. $P_{2} O_{5}\left(\mathrm{mg} \mathrm{kg}^{-1}\right)$} & \multicolumn{4}{|c|}{ Exchangeable cations } & \multirow[t]{3}{*}{ CEC (cmolc kg $\left.{ }^{-1}\right)$} \\
\hline & & & & & $\mathrm{K}$ & $\mathrm{Ca}$ & $\mathrm{Mg}$ & $\mathrm{Na}$ & \\
\hline & & & & & \multicolumn{4}{|c|}{$\left(\mathrm{cmolc} \mathrm{kg}^{-1}\right)$} & \\
\hline$C L$ & 7.28 & 0.73 & 17.3 & 289 & 0.89 & 9.11 & 2.06 & 0.11 & 9.1 \\
\hline
\end{tabular}

Table 2 Chemical composition of food waste compost mixed within the $10 \mathrm{~cm}$ depth of the potted surface soil

\begin{tabular}{llllllll}
\hline $\mathbf{C}(\%)$ & $\mathbf{C} / \mathbf{N}$ & $\mathrm{TN}$ & $\mathbf{P}_{\mathbf{2}} \mathbf{O}$ & $\mathbf{K}_{\mathbf{2}} \mathbf{O}$ & $\mathrm{CaO}$ & $\mathbf{M g O}$ & $\mathbf{N a C l}$ \\
\hline 41.4 & $1 \%)$ & & & & & \\
\hline
\end{tabular}


extracted with $50 \mathrm{~mL}$ of $1 \mathrm{M} \mathrm{NH}_{4} \mathrm{OAc}$ for $3 \mathrm{~h}$. Ex. Na was determined ICP-AES in this solution. Secondly, $0.2 \mathrm{M}$ $\mathrm{CaCl}_{2}$ re-extracted $\mathrm{NH}_{4}$ ion from remained soil. Kjeldahl methods were employed in the measurement of the $\mathrm{NH}_{4}{ }^{+}$concentrations. Exchangeable sodium percentage (ESP) was calculated as the proportion of exchangeable $\mathrm{Na}^{+}$to cation exchange capacity (CEC).

\section{Microbial community composition}

Microbial community composition was determined using the modified ester-linked fatty acid method. This method was conducted in three steps. Firstly, fatty acid was extracted from $3 \mathrm{~g}$ of lyophilized soil with $10 \mathrm{~mL}$ of $0.2 \mathrm{M} \mathrm{KOH}$ for $1 \mathrm{~h}$ at $37^{\circ} \mathrm{C}$ on $180 \mathrm{rpm}$ of orbital steering. Then, solution $\mathrm{pH}$ was adjusted with $1.0 \mathrm{M}$ acetic acid and inserted $10 \mathrm{~mL}$ of $\mathrm{n}$-hexane was poured into $50 \mathrm{~mL}$ centrifuge tube. After vortexing for $1 \mathrm{~min}$, the mixture solution was centrifuged at $1600 \mathrm{rpm}$ for $20 \mathrm{~min}$. Finally, $5 \mathrm{~mL}$ of the supernatant (hexane layer) was transferred into a $10 \mathrm{~mL}$ tube and evaporated to $\mathrm{N}_{2}$ gas. The residue was dissolved in $170 \mu \mathrm{L}$ of $1: 1$ solution of hexane and methyl-t-butyl ether, and then $30 \mu \mathrm{L}$ of $0.01 \mathrm{M}$ methyl nonadecanoate (19:0) was added as an internal fatty acid. Fatty acid was quantified and identified using a Hewlett-Packard 5890 Series II (Palo Alto, CA) and MIDI software following MIDI microbial calibration standards. HP Ultra 2 capillary column (5\% diphenyl-95\% dimethylpolysiloxane, $25 \mathrm{~m}$ by 0.2 ) was used with column temperatures varied between 170 and $270{ }^{\circ} \mathrm{C}$ at $5{ }^{\circ} \mathrm{C}$ per min. Total FAME summed each fatty acid quantity. Total

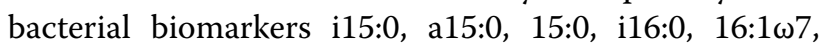

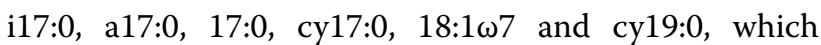
used branched fatty acids of iso- and ante iso series for $\operatorname{gram}(+)$ and cy17:0 for gram(-) bacteria were utilized. Fungi bio-markers used were: $18: 2 \omega 6,9$ and $18: 3 \omega 6$ while The 16:l $\omega 5$ served as arbuscular mycorrhiza. Fungal to bacterial ratio was determined from the total fungi and bacteria bio-markers (n mol g $\left.{ }^{-1}\right)$.

\section{Data analysis}

All data were analyzed with a general linear model in $\mathrm{R}$ 3.5.2. The least significant difference deviations (LSD) of the mean values of each plot were compared through ANOVA test at $p<0.05$. To analyze the change of microbial community composition, a principal component analysis (PCA) was performed on the proportion of individual fatty acids as mol\%. Principle component (PC) score was assessed by using ANOVA at $p<0.05$. Redundancy analysis (RDA) was used to test the relationships between soil properties and microbial community composition in soil under different water conditions and food waste compost application rates. The contribution of soil properties to changes in soil microbial composition was assessed with the Monte Carlo permutation test observing strict adherence to the 999 random permutations basing on p-levels $<0.05$ [12]. Soil properties significantly correlated with the changes in microbial community composition in the plot. Vectors of greater magnitude and forming smaller angles with an axis were more strongly correlated with that axis $[13,14]$.

\section{Results and discussion}

\section{Soil properties}

Applying organic matter to the soil can also improve its properties and promote effective decomposition by increasing the activity of soil microbes thus enhancing agricultural production [15]. The application of food waste compost to saturated and unsaturated soils had a significant effect on the soil properties (Table 3). All rates of food waste compost applied to both saturated and unsaturated soils increased soil $\mathrm{pH}, \mathrm{EC}, \mathrm{T}-\mathrm{C}, \mathrm{T}-\mathrm{N}$, Ex. $\mathrm{Na}$, and ESP as were determined after harvesting rice and pepper. Studies by Lou et al. [16] and Abro et al. [17] indicated that addition of organic amendments into soil increased soil carbon and nitrogen contents subsequently improving soil quality. Soil organic carbon in our current study was higher in saturated soil as compared to unsaturated one. The reason for this observation might lie in the differences in the degree of soil water saturation between the rice and pepper cultivated soils. Microbial degradation of organic matter in the soil is dependent on oxygen availability which in turn relates to the water saturation levels with slower rates of degradation reported in anoxic soil conditions $[18,19]$. Degradation of soil organic carbon in the saturated soil might be restricted carbon substrate availability by microbes as well as oxygen supply into the soil. In contrast, aerobic soil condition would highly influence at the decomposition of soil organic carbon compared to the saturated paddy like anoxic status.

Soil pH and EC might be important factors crop productivity as well as microbial population and activity in the soil. Nutrient supply from soil to plant could be affected by declines in microbial population and activity caused by $\mathrm{Na}$ ions released from food waste compost into the soil. As Lou et al. [16] and Abro et al. [17] found Soil $\mathrm{pH}$ could change the microbial composition because the bacteria population was dominant at around neutral $\mathrm{pH}$ [20]. As shown in Table 3, soil pH slightly increased with increasing food waste compost application rates and the patterns of increment were similar in both soil water saturation conditions. These results therefore, indicate that food waste compost might impact the microbial status of the soil through raising soil $\mathrm{pH}$. Besides soil $\mathrm{pH}$ and $\mathrm{EC}$ contents could also affect crop growth by inhibiting water uptake and inducing ion toxicity around the rhizosphere [21]. Rice grain yield decreased with the increasing rates 
Table 3 Yields and chemical properties in soil applied with food waste after harvesting rice and pepper at harvesting stage

\begin{tabular}{|c|c|c|c|c|c|c|c|c|c|}
\hline Crops & Treatment & $\mathrm{pH}(1: 5)$ & $E C\left(d S m^{-1}\right)$ & $\mathrm{TC}\left(\mathrm{g} \mathrm{kg}^{-1}\right)$ & $\mathrm{TN}\left(\mathrm{g} \mathrm{kg}^{-1}\right)$ & $\mathrm{CN}\left(\mathrm{mg} \mathrm{kg}^{-1}\right)$ & $\begin{array}{l}\text { Ex. } \mathrm{Na} \\
\left(\mathrm{cmolc} \mathrm{kg}^{-1}\right)\end{array}$ & ESP (\%) & Yields (g plant ${ }^{-1}$ ) \\
\hline \multirow[t]{6}{*}{ Rice } & 0 & 7.16 & 0.32 & 9.01 & 0.76 & 11.9 & 0.24 & 1.76 & $25.2^{\mathrm{a}}$ \\
\hline & 10 & 7.31 & 0.35 & 11.11 & 1.00 & 11.1 & 0.24 & 1.91 & $25.6^{\mathrm{a}}$ \\
\hline & 20 & 7.38 & 0.35 & 13.25 & 1.22 & 10.9 & 0.25 & 1.86 & $23.1^{\mathrm{a}}$ \\
\hline & 40 & 7.77 & 0.43 & 17.65 & 1.70 & 10.4 & 0.25 & 1.65 & $11.9^{b}$ \\
\hline & 60 & 7.81 & 0.65 & 18.72 & 1.86 & 10.1 & 0.29 & 2.06 & $3.4^{c}$ \\
\hline & $\mathrm{LSD}_{0.05}$ & 0.24 & 0.06 & 2.20 & 0.36 & 0.12 & 0.03 & 0.37 & 7.23 \\
\hline \multirow[t]{6}{*}{ Pepper } & 0 & 7.46 & 0.43 & 9.82 & 0.81 & 12.1 & 0.20 & 2.28 & $138.3^{d}$ \\
\hline & 10 & 7.66 & 0.53 & 11.21 & 1.02 & 11.0 & 0.31 & 3.45 & $167.1^{\mathrm{cd}}$ \\
\hline & 20 & 7.75 & 0.61 & 11.15 & 1.02 & 10.9 & 0.36 & 3.23 & $207.9^{\mathrm{ab}}$ \\
\hline & 40 & 7.95 & 0.69 & 12.78 & 1.16 & 11.0 & 0.36 & 3.17 & $219.9^{\mathrm{a}}$ \\
\hline & 60 & 7.98 & 0.98 & 16.89 & 1.65 & 10.3 & 0.64 & 5.55 & $183.4^{\mathrm{bc}}$ \\
\hline & $\mathrm{LSD}_{0.05}$ & 0.11 & 0.33 & 2.12 & 0.21 & 0.35 & 0.08 & ns & 30.5 \\
\hline \multicolumn{2}{|c|}{$\operatorname{Crop}(A)$} & $* * *$ & $* * *$ & $* * *$ & $* * *$ & $* * *$ & $* * *$ & $* * *$ & $* * *$ \\
\hline \multicolumn{2}{|c|}{ Food waste compost (B) } & $* * *$ & $* * *$ & $* * *$ & $* * *$ & $* *$ & $* * *$ & * & $* * *$ \\
\hline \multicolumn{2}{|c|}{$A \times B$} & ns & Ns & $* * *$ & $* * *$ & $* *$ & * & ns & $* * *$ \\
\hline
\end{tabular}

Means followed by a common letter are not significantly different

ESP exchangeable sodium percentage, $L S D$ least significant difference test $(p<0.05)$

${ }^{*}, * *$ and ${ }^{* * *}$ denotes significance at 5,1 and $0.1 \%$ level, respectively

of food waste compost applied. Conversely, pepper yield increased with increasing rates of food waste compost up to the rate of $40 \mathrm{Mg} \mathrm{ha}^{-1}$ beyond which it declined. Therefore, food waste compost application affects soil properties, nutrients availability and increases potential risks for retardation of crop productivity.

\section{Microbial community composition}

Adding organic materials to soil is very important in increasing soil organic carbon levels and improving soil fertility and soil microbial activity [22-24]. The microbial community composition shown in Table 4 indicates that food waste compost application enhanced the total PLFA significantly in the two soil water management conditions under rice and pepper cultivation. However, total PLFA in unsaturated soil with pepper cultivation was higher than in the saturated soil. Fugal PLFA was enhanced with increasing application rates of food waste compost in both the saturated and unsaturated soil conditions while the changes in bacterial PLFA differed across the saturated and unsaturated soils. Unsaturated soil conditions culminated into enhanced total bacterial PLFA, i.e. both gram-positive and gram-negative bacteria, although the gram-positive bacteria were the most dominant group. However, there was no observable change in total bacterial PLFA when food waste compost was applied to the saturated soil. Nevertheless, gram-negative bacteria were the most dominant type under this soil condition.
Irrespective of soil water saturation conditions, the relative fugal PLFAs positively correlated with food waste compost application rates and their concentrations were significantly higher than bacterial PLFAs at any given compost application rate.

Individual PLFAs of the soil microbes may be sensitive indicators of soil water condition $[25,26]$. The ratio of fungal-to-bacterial PLFAs is an important indicator of the changes in the relative abundance of soil microbial communities [27, 28]. The differences in fungal to bacterial PLFA ratios between the two soil water conditions would have been due to differences in carbon substrate availability and osmotic pressure induced by food waste compost. It has been reported that fungi contribute to the nutrient cycling recalcitrant $\mathrm{C}$, thereby improving soil structure [29-31]. Fungal PLFA composition increased with increasing application rates of food waste compost in both saturated and unsaturated soils because fungi converted the recalcitrant carbon contained in food waste in labile $\mathrm{C}$ forms which proliferated microbial generation as indicated by Cao et al. [13]. There are several previously concluded studies for example by Frostegård et al. [27] and, Bååth and Anderson [28] that have reported high fungal-to-bacterial PLFA ratios due to the higher SOC levels in agricultural soils. The variations in the two kinds of bacteria (gram positive and negative bacteria) were due to differences in soil salinity tolerance. Gram-positive bacteria are highly tolerant to salt because 
Table 4 Microbial community in the soil of paddy and upland applied food waste compost at harvest stages

\begin{tabular}{|c|c|c|c|c|c|c|c|c|c|c|}
\hline \multirow[t]{2}{*}{ Crops } & \multirow[t]{2}{*}{ FWC $\left(\mathrm{Mg} \mathrm{ha}^{-1}\right)$} & \multirow{2}{*}{$\begin{array}{l}\text { T-FAME } \\
\left(\mathrm{nmol} \mathrm{g}^{-1}\right)\end{array}$} & \multicolumn{4}{|c|}{ Bacteria $\left(\mathrm{nmol} \mathrm{g}^{-1}\right)$} & \multirow[t]{2}{*}{ Fungi $\left(\mathrm{nmol} \mathrm{g}^{-1}\right)$} & \multirow[t]{2}{*}{ AMF $\left(\mathrm{nmol} \mathrm{g}^{-1}\right)$} & \multirow[t]{2}{*}{$\mathrm{F} / \mathrm{B}$} & \multirow[t]{2}{*}{$G(+) / G(-)$} \\
\hline & & & Total & $G(+)$ & $\mathrm{G}(-)$ & Act. & & & & \\
\hline \multirow[t]{6}{*}{ Rice } & 0 & 410.5 & 229.0 & 65.0 & 78.0 & 7.9 & 70.7 & 20.0 & 0.397 & 0.836 \\
\hline & 10 & 374.7 & 205.8 & 50.4 & 67.4 & 7.8 & 74.9 & 12.4 & 0.424 & 0.756 \\
\hline & 20 & 420.4 & 225.8 & 61.3 & 69.0 & 6.8 & 88.4 & 12.4 & 0.446 & 0.887 \\
\hline & 40 & 454.0 & 235.7 & 63.6 & 74.6 & 7.7 & 101.4 & 12.5 & 0.483 & 0.854 \\
\hline & 60 & 468.7 & 210.4 & 48.6 & 68.2 & 7.3 & 131.2 & 10.8 & 0.674 & 0.713 \\
\hline & $\operatorname{LDS}_{0.05}$ & 44.3 & 19.6 & 7.78 & ns & ns & 16.5 & 2.3 & 0.063 & 0.144 \\
\hline \multirow[t]{6}{*}{ Pepper } & 0 & 475.1 & 226.5 & 37.4 & 76.9 & 5.1 & 122.7 & 68.2 & 0.851 & 0.481 \\
\hline & 10 & 432.4 & 199.7 & 33.6 & 63.5 & 6.5 & 110.2 & 70.8 & 0.910 & 0.532 \\
\hline & 20 & 573.9 & 253.5 & 33.1 & 78.5 & 5.2 & 152.9 & 106.3 & 1.023 & 0.414 \\
\hline & 40 & 595.2 & 259.1 & 53.1 & 77.5 & 11.3 & 160.1 & 102.5 & 1.014 & 0.685 \\
\hline & 60 & 611.4 & 260.6 & 60.9 & 80.0 & 10.0 & 175.9 & 89.0 & 1.018 & 0.756 \\
\hline & $\operatorname{LDS}_{0.05}$ & 72.4 & 38.7 & 13.6 & 11.1 & ns & 22.6 & 15. & 0.090 & 0.102 \\
\hline \multicolumn{2}{|l|}{$\operatorname{Crop}(A)$} & $* * *$ & * & $* * *$ & * & * & $* * *$ & $* *$ & $* * *$ & $* * *$ \\
\hline \multicolumn{2}{|c|}{ Food waste compost (B) } & $* * *$ & $* * *$ & ** & $*$ & ns & $* * *$ & * & $* *$ & * \\
\hline \multicolumn{2}{|l|}{$A \times B$} & * & * & $* * *$ & $* *$ & ns & ns & ns & * & $* * *$ \\
\hline
\end{tabular}

We assigned the following biomarkers to specific microbial groups: bacteria (sum of were i15:0, a15:0, 15:0, i16:0, 16:1 $\omega 7 c$, i17:0, a17:0, 17:0, cy17:0, 18:1 $\omega 7$ and

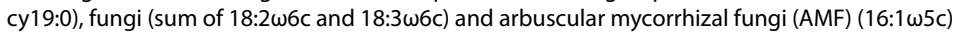

T-PLFA total phospholipid fatty acid, Gram(+) gram positive bacteria, Gram(-) gram negative bacteria, F/B fungi to bacterial ratio, T-PLFA sum of fatty and methyl esters and 26FAMEs were detected, $L S D$ least significant difference test $(\mathrm{p}<0.05)$

**** and ${ }^{* * *}$ denotes significance at 5,1 and $0.1 \%$ level, respectively

their peptidoglycan layers the in cell wall are thicker than those of the gram-negative bacteria. That kind of a cell structure is most likely to render resistance to changes in osmotic pressure triggered by changes in the soil environment such as salinity and soil saturation as was in the current study. Our results therefore, indicate that food waste compost induced changes in microbial community composition depending on the degree of soil water saturation.

\section{Relationship between soil microbial community composition and soil properties}

Microbial communities respond to alterations in the soil environment. The principal components analysis (PCA) was conducted to confirm the changes in the microbial community compositions in the soils at two different saturation levels treated with food waste compost. The PC 1 and PC 2 in the PCA bi-plot attributed 60.7 and 11.4\% of the total variation in the microbial community to the rate of food waste compost applied in both the saturated and unsaturated soils (Fig. 1). The microbial community varied distinctly between the saturated and unsaturated soil and changed with levels of food waste compost. The microbial community composition correlated significantly with the $\mathrm{PC} 1(\mathrm{r}=0.67, \mathrm{p}<0.01)$ and $\mathrm{PC} 2$ $(\mathrm{r}=0.42, \mathrm{p}<0.01)$ axis. In this study, bacteria community was shown different patterns under water regimes with

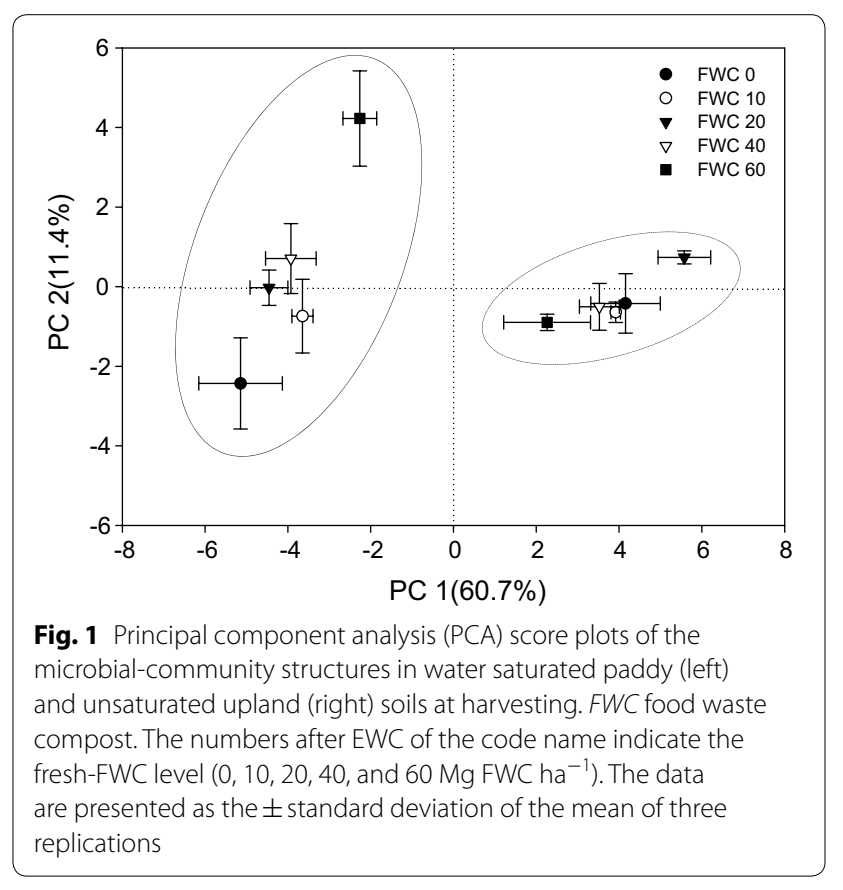

food waste compost application. Especially, Gram positive bacteria significantly decreased in water saturated soil (Table 4), but fungi and AM fungi increased under water saturated and unsaturated soils. Water status was 


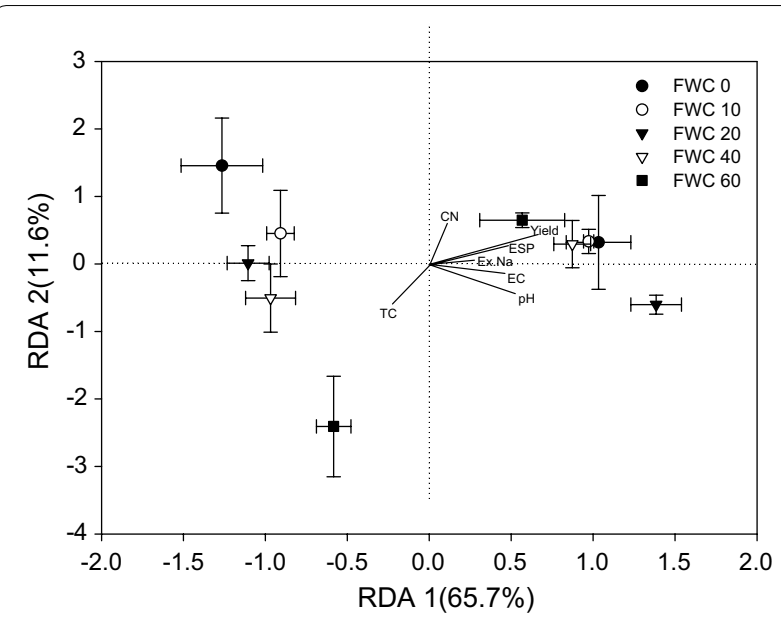

Fig. 2 Relationship between microbial communities and soil in water saturated paddy (left) and unsaturated upland (right) soils at harvesting. FWC food waste compost. The numbers after FWC of the code name indicate the fresh-FWC level $(0,10,20,40$, and 60 Mg FWC $\left.\mathrm{ha}^{-1}\right)$. The data are presented as the \pm standard deviation of the mean of three replications an important factor for soil microbial community due to nutrient availability such as carbon substrates $[11,32$, 33]. Soil water regimes for crop cultivation might affect the partitioning and allocation of plant photosynthathes by depending soil nutrient status [34]. Also, roots exduates composition might be key factors affecting the shifts of soil microbial communities [35, 36].

Redundancy analysis (RDA) was utilized to test the relationship between the microbial community composition and soil properties at different rates of food waste compost and in varying soil water conditions. The environmental variables $\mathrm{pH}, \mathrm{EC}, \mathrm{TC}, \mathrm{TN}, \mathrm{CN}, \mathrm{Ex} . \mathrm{Na}, \mathrm{ESP}$, and yield were used to determine Monte Carlo permutation tests $(\mathrm{p}<0.05)$. Seven environmental variables significant on the first axis $(F=21.12, p<0.01)$ and all canonical axes $(\mathrm{F}=4.60, \mathrm{p}<0.01)$. TC $(\mathrm{F}=11.03, \mathrm{p}<0.01)$, $\mathrm{EC}(\mathrm{F}=8.35, \mathrm{p}<0.01)$, soil $\mathrm{pH}(\mathrm{F}=5.07, \mathrm{p}<0.01)$, and Yield $(\mathrm{F}=2.84, \mathrm{p}<0.05)$ were influenced with the variations in microbial community composition. The distinct differences in the microbial communities of the saturated and unsaturated soils resulted from differences in total carbon, and was associated with lower $\mathrm{pH}$ values and salinity (Fig. 2). Soil microbial communities was affected from the changes of soil environmental condition under soil water regimes with organic amendments.

\section{Acknowledgements}

This study was supported by Rural Development Administration (PJ010925), Republic of Korea.

Chang Hoon Lee is the first author.

\section{Authors' contributions}

CHL, SJP and MSK conceived and designed the experiments. CHL, HYK and SHK conducted the experiments, analyzed the data and generated the figure and tables. HYH, HIJ, DL, and SYH reviewed the results of experiments and examined English grammar of the manuscript. CHL, TKO and SHK supervised the whole project and CHL and SHK wrote the manuscript. All authors read and approved the final manuscript.

\section{Funding}

No funding was received.

\section{Availability of data and materials}

The datasets supporting the conclusions of this article are including within the article.

\section{Competing interests}

The authors declare that they have no competing interests.

\section{Author details}

${ }^{1}$ Department of Fruit Science, Korea National College of Agriculture and Fisheries, Jeonju 54874, Korea. ${ }^{2}$ Soil and Fertilizer Division, National Institute of Agriculturaal Sciences, RDA, Wanju 55365, Korea. ${ }^{3}$ Department of Bio-Environmental Chemistry, Chungnam National University, Daejeon 34134, Korea.

Received: 24 May 2019 Accepted: 11 July 2019

Published online: 19 July 2019

\section{References}

1. Lee CH, Park SJ, Kim MS, Yun SG, Ko BG, Lee DB, Kim SC, Oh TK (2015) Characteristics of compost produced in food waste processing facility. CNU J Agric Sci 42(3):177-181

2. Lee SB, Lee CH, Jung KY, Park KD, Lee DK, Kim PJ (2009) Changes of soil organic carbon and its fraction in relation to soil physical properties in a long-term fertilized paddy. Soil Tillage Res 104:227-232

3. Lee CH, Ko BG, Kim MS, Park SJ, Yun SG, Oh TK (2016) Effect of food waste compost on crop productivity and soil chemical properties under rice and pepper cultivation. Korean J Soil Sci Fertil 49(6):682-688

4. Juteau P (2006) Review of the use of aerobic thermophilic bioprocesses for the treatment of swine waste. Livest Sci 102:187-196

5. Marschner P, Kandeler E, Marschner B (2003) Structure and function of the soil microbial community in a long-term fertilizer experiment. Soil Biol Biochem 35:453-461

6. Fierer N, Lauber CL, Ramirez KS, Zaneveld J, Bradford MA, Knight R (2012) Comparative metagenomic, phylogenetic and physiological analyses of soil microbial communities across nitrogen gradients. ISME J 6:1007-1017

7. Lee GJ, Kang BG, Kim KS (2015) Effect of fertigation by soil testing application level on the growth of young jujube tree and soil chemical properties on sprinkler type irrigation. Korean J Int Agric 27(2):226-230

8. Kelley WD, Martens DC, Reneau RB, Simpson TW Jr (1984) Agricultural use of sewage sludge: a literature review. Department of Agronomy, Virginia Polytechnic Institute and State University Virginia Water Resources Research Center, Blacksburg, pp 3397-24060

9. Singh RP, Agrawal M (2008) Potential benefits and risks of land application of sewage sludge. Waste Manag Res 28:347-358

10. Tian J, Dippold M, Pausch J, Blagodatskaya E, Fan M, Li X, Kuzyakov Y (2013) Microbial response to rhizodeposition depending on water regimes in paddy soils. Soil Biol Biochem 65:195-203

11. Lagomarsino A, Agnelli AE, Pastorelli R, Pallara G, Rasse DP, Silvennoinen H (2016) Past water management affected GHG production and microbial community pattern in italian rice paddy soils. Soil Biol Biochem 93:17-27

12. Manly BFJ (ed) (2006) Randomization, bootstrap and Monte Carlo methods in biology. Chapman \& Hall/CRC, London

13. Cao YS, Fu SL, Zou XM, Cao HL (2010) Soil microbial community composition under Eucalyptus plantations of different age in subtropical China. Eur J Soil Biol 46:128-135

14. Zornoza R, Guerrero C, Mataix-Solera J, Scow KM (2009) Changes in soil microbial community structure following the abandonment of 
agricultural terraces in mountainous areas of Eastern Spain. Appl Soil Ecol 42:315-323

15. Shen YY, Chen H (2009) The progress of study on soil improvement research with straw stalk. Chin Agric Sci Bull 25:291-294 (in Chinese)

16. Lou YL, Liang WJ, Xu MG, He XH (2011) Straw coverage alleviates seasonal variability of the topsoil microbial biomass and activity. CATENA 86:117-120

17. Abro SA, Tian X, Wang X, Wu F (2011) Decomposition characteristics of maize (Zea mays L.) straw with different carbon to nitrogen $(\mathrm{C} / \mathrm{N})$ ratios under various moisture regimes. Afr J Biotechnol 10:10149-10156

18. Kazuyki I, Wada H, Takai Y (1983) Easily decomposition organic matter in paddy soil. Soil Sci Plant Nutr 30(2):189-198

19. Yun HB, Lee Y, Yu CY, Lee SM, Hyun BK, Lee YB (2007) Effects of cruise carbohydrate content in livestock manure compost on organic matter decomposition rate in upland soil. Korean J Soil Sci Fertil 40(5):364-368

20. Keum MJ, Yoon MH, Nam IH (2015) Effects of heavy metal and pH on bacterial growth isolated from the contaminated swelter soil. J Soil Groundw Environ 20(4):113-121

21. Greenway H, Munns R (1980) Mechanisms of salt tolerance in non-halophytes. Annu Rev Plant Physiol 31:149-190

22. Crecchio C, Curci M, Mininni R, Ricciuti P (2001) Short-term effects municipal solid waste compost amendment on soil carbon and nitrogen content, some enzyme activities and genetic diversity. Biol Fertil Soils 34:311-318

23. Leroy BLM, Herath HMSK, Sleutel S, De Neve S (2008) The quality of exogenous organic matter: short-term effects on soil physical properties and soil organic matter fractions. Soil Use Manag 24:139-147

24. Cayuela ML, Sinicco T, Mondini C (2009) Mineralization dynamics and biochemical properties during initial decomposition of plant and animal residues in soil. Appl Soil Ecol 41:118-127

25. Grayston SJ, Campbell CD, Bardgett RD, Mawdsley JL (2004) Assessing shifts in microbial community structure across a range of grasslands of differing management intensity using CLPP, PLFA and community DNA techniques. Appl Soil Ecol 25:63-84

26. Zhang TL, Li ZP, Wang XX (2006) Soil degradation and its eco-environmental impact under highly-intensified agriculture. Acta Pedol Sin 34:843-850 (in Chinese)
27. Frostegård A, Tunlid A, Bååth E (1993) Phospholipid fatty acid composition, biomass, and activity of microbial communities from two soil types experimentally exposed to different heavy metals. Appl Environ Microbiol 59(11):3605-3617

28. Bååth E, Anderson TH (2003) Comparison of soil fungal/bacterial ratios in a pH gradient using physiological and PLFA-based techniques. Soil Biol Biochem 35:955-963

29. Hodge A, Campbell CD, Fitter AH (2001) An arbuscular mycorrhizal fungus accelerates decomposition and acquires nitrogen directly from organic material. Nature 413:297-299

30. Wu YQ, Jiang JZ, Shen WK, He XL (2010) Arbuscular mycorrhiza fungi as an ecology indicator for evaluating desert soil conditions. Front Agric Chin 4:24-30

31. Oehl F, van der Heijden M, Jansa J, Ineichen K (2011) Arbuscular mycorrhizal fungi as bio-indicators in Swiss agricultural soils. Agrarforschung Schweiz 2:304-311

32. Bassio DA, Fleck JA, Scow KM, Fujii R (2006) Alteration of soil microbial communities and water quality in restored wetlands. Soil Biol Biochem 38:1223-1233

33. Unger IM, Kennedy AC, Muzika RM (2009) Flooding effects on soil microbial communities. Appl Soil Ecol 42:1-8

34. Meharg AA, Kilham K (1990) Carbon distribution within the plant and rhizosphere for Lolium perenne subjected to anaerobic soil conditions. Soil Biol Biochem 22:643-647

35. Paterson E, Gebbing T, Abel C, Sim A, Telfer G (2007) Rhizodeposition shapes rhizosphere microbial community structure in organic soil. New Phytol 173:600-610

36. Tian J, Fan MS, Guo JH, Marschner P, Li XL, Kuzyakov Y (2012) Effetcs of land use intensity on dissolved organic carbon properties and microbial community structure. Eur J Soil Biol 52:67-72

\section{Publisher's Note}

Springer Nature remains neutral with regard to jurisdictional claims in published maps and institutional affiliations.

\section{Submit your manuscript to a SpringerOpen ${ }^{\circ}$ journal and benefit from:}

- Convenient online submission

- Rigorous peer review

- Open access: articles freely available online

- High visibility within the field

- Retaining the copyright to your article

Submit your next manuscript at $\boldsymbol{\nabla}$ springeropen.com 